\title{
DYSTRYBUCJA FILMOWA. FAKTY I MITY
}

\author{
ANNA WRÓBLEWSKA Wydział Nauk Humanistycznych Uniwersytet Kardynała Stefana Wyszyńskiego; \\ Faculty of Humanities Cardinal Stefan Wyszyński University in Warsaw (Poland). \\ annadorotawroblewska@gmail.com
}

\section{1 i 22 października 2014 roku Wydział Organizacji Sztuki Filmowej} w Szkole Filmowej w Lodzi zorganizowal konferencję Dystrybucja filmowa. Fakty $i$ mity. To pierwsza konferencja naukowo-branżowa poświęcona tej tematyce.

Konferencje Szkoły Filmowej w Łodzi mają specyficzny charakter. PWSFTViT to uczelnia o wyjątkowej renomie w dziedzinie kształcenia artystycznego. W tym roku prestiżowy magazyn „Hollywood Reporter” przedstawił klasyfikację najlepszych nieamerykańskich szkół filmowych. Na drugim miejscu po słynnej National Film and Television School z Londynu znalazła się Szkoła Filmowa w Łodzi, wyprzedzając tym samym paryską Le Femis, sklasyfikowaną jako trzecią. Magazyn podkreślił, że założona w 1948 roku PWSFTviT w Łodzi ,wykształciła panteon wielkich ludzi kina, wśród których jest zdobywca Oscara Roman Polański”. Wśród grona absolwentów wymienia takie nazwiska, jak: Jerzy Skolimowski, Krzysztof Zanussi, Zbigniew Rybczyński, Krzysztof Kieślowski, Adam Holender, Witold Sobociński, Sławomir Idziak, Paweł Edelman, „zdobywców Oscara i laureatów nagród w Wenecji, Cannes, Berlinie”. Magazyn zwraca również uwagę na to, że co roku na uczelni powstaje ponad 300 filmów studenckich, z czego połowa realizowana jest na taśmie $35 \mathrm{~mm}$.

Domeną Szkoły Filmowej w Łodzi (to druga, oficjalna nazwa placówki) jest więc kształcenie artystyczne. Stawia to w specyficznej sytuacji Wydział 
Organizacji Sztuki Filmowej w Łodzi, który kształci producentów i kierowników produkcji. Wydział ten uczy z jednej strony konkretnego zawodu, z drugiej zaś - zobligowany jest do rozwoju naukowego. Od 2013 roku dziekan Wydziału dr Roman Sawka regularnie organizuje więc konferencje naukowe. Po wielkiej konferencji poświęconej tradycji zespołów filmowych uwieńczonej publikacją, a także międzywydziałowej konferencji poświęconej relacjom producenta i aktora, zorganizowano w październiku 2014 roku sympozjum dotyczące dystrybucji, które w umiejętny sposób połączyło dyskurs naukowy - nader rzadki w tym obszarze - z kompetencjami wybitnych praktyków, wiele lat obecnych w branży filmowej. Wnioski z tego spotkania są niezwykle interesujące.

Dr Magdalena Sobocińska z Uniwersytetu Wrocławskiego, autorka książki Zachowania nabywców na rynku dóbr i usług kultury wystąpienie swoje poświęciła zagadnieniom marketingu w nowoczesnej dystrybucji. Przesłankami do rosnącej roli promocji filmu są globalizacja i umiędzynarodowienie obiegu dóbr kultury - mówiła badaczka. - Ale także twórcy nie chcą, aby ich filmy pozostawały w obiegu peryferyjnym.

Zdaniem Sobocińskiej, rozwój rynku kinowego będzie zależał od tych, którzy nie chodzą, a być może zaczną chodzić do kina. Kluczowe jest więc pytanie, jak należy prowadzić promocję, by objąć nią skutecznie wszystkich obecnie „wykluczonych”. Przytoczyła typologię widzów według Tomasza Szlendaka. Grupa odbiorców filmu składa się z takich podgrup, jak: środowisko artystyczne, „wyznawcy” (czyli odbiorcy sztuki wysokiej), ,poszukiwacze awangardy i selekcjonerzy treści”, dzieci i młodzież, mieszczanie z wyrzutami sumienia (np. klienci galerii, którzy czasem przychodzą też do kina), grona towarzyskie, aktywni emeryci i „,parakulturalni”. Zdaniem badaczki, aby dotrzeć do wszystkich tych grup, trzeba stosować bardzo różne formy promocji, umiejętnie godząc tę tradycyjną i tę skupioną na nowych mediach. Są to tak różne formy, jak targi, pitchingi (czyli prezentacje projektów w realizacji), reklama telewizyjna, prasowa, Internetowa, piosenka 
filmowa, tytuł, reklama zewnętrzna, billboardy, reklama na środkach transportu, merchandising (czyli sprzedaż produktów powiązanych z filmem).

Każda z grup odbiorców ma inną motywację do uczestnictwa w kulturze i pod nią trzeba inaczej, świadomie programować działania kulturalne. Skuteczność promocji zależy w dużej mierze od trafienia w odpowiednią motywację, ale także od tego, na ile da się pokonać mechanizmy obronne widzów. Wielość mediów sprawia, że nie jesteśmy w stanie wszystkiego oglądać i słuchać.

Istotne jest także różnicowanie promocji poszczególnych tytułów, kreowanie marki filmu, na którą wpływają tak różne czynniki jak wizerunek twórców, aktorów, sytuacja odbioru (czy film oglądany jest przede wszystkim w multipleksach, czy w kinach studyjnych), sumy doświadczeń odbiorców. - Czas wolny się kurczy, widz oferuje nam, oprócz czasu, swoją wrażliwość. De facto kreatorem marki może być dzisiaj odbiorca. W kontekście siły Internetu on ma znaczenie - mówiła Sobocińska. - Efektywność promocji należy badać w sposób bardzo złożony.

Profesor Ewa Gębicka z Uniwersytetu Śląskiego, od wielu lat badająca produkcję i dystrybucję filmową w Polsce, swoje wystąpienie skoncentrowała przede wszystkim na promocji w nowych mediach. - Marzeniem producenta i dystrybutora jest realizacja filmu, który pogodzi sukces artystyczny z komercyjnym. Ten drugi jest wypadkową wielu czynników, nie zawsze zależnych od twórców. Na pewno drogą do tego jest pomysłowa kampania promocyjna, zarówno tradycyjna, jak i w nowych mediach, poprzez Internet i nośniki komunikatów - mówiła profesor Gębicka, opierając się na przykładach z rynku amerykańskiego. - Skuteczność Internetu wynika z jego efektów, ma on charakter globalny, multimedialny, umożliwia bezpośredni kontakt $\mathrm{z}$ widzem $\mathrm{i}$ indywidualizację oferty.

Jak zwróciła uwagę badaczka, ze szczególnych atutów Internetu szybko zdał sobie sprawę przemysł audiowizualny. Wielkie studia coraz chętniej zwiększają budżety na działania online. W sytuacji konkurencji te strategie 
muszą być bardziej skuteczne, wykorzystywać sprzedaż produktów, merchandising, a materiały promocyjne pełnią nie tylko rolę informacyjną, lecz także stają się źródłem przyjemności widza. Aktualna lista nośników reklamy zawiera kilkadziesiąt pozycji. Choć oczywiście polscy producenci i dystrybutorzy mają ograniczone budżety, warto zwrócić uwagę na pomysły zza oceanu w sposób twórczy wykorzystujące właściwości nowych mediów. A często taka reklama może być dla naszego rynku atrakcyjna cenowo. Przewiduje się, że tradycyjna reklama graficzna z czasem ustąpi reklamie w wyszukiwarkach, pójdzie w kierunku łagodniejszych form promocji, dostosowanych do potrzeb internautów - mówiła profesor Gębicka. Przytaczała takie formy promocji, jak strony www o charakterze nie tylko ,wizytówkowym", lecz także eventowym lub sprzedażowym, chatroomy, fora dyskusyjne, bogi, mikroblogi, social media. - Za pomocą wirtualnego kontaktu fani odczuwają realny związek z otoczeniem - powiedziała badaczka.

Wśród prelegentów na konferencji przeważali praktycy, co nie jest zaskakujące w sytuacji, gdy nurt ,produkcyjny” jest nader rzadko uprawianą dziedziną nauk filmowych. Dialog naukowców z profesjonalistami z branży filmowej był zdecydowanie dobrym pomysłem. Sławomir Salamon, szef Forum Film Poland, wybitny znawca rynku filmowego, polemizując z badaczkami zwracał uwagę, że, doceniając nowe alternatywne formy promocji, dystrybutor na razie jeszcze stawia przede wszystkim na tradycyjne ścieżki. A przykłady niezwykle skutecznych kampanii alternatywnych, jak w przypadku filmu Blair Witch Project, nadal pozostają jedynie wyjątkami. Kino to najefektywniejsze pole zwrotu nakładów, a marketing polegający na wykupieniu czasu reklamowego w mediach nadal stanowi jedno z najskuteczniejszych narzędzi promocji. - „Publicity”, po polsku PR - nie sprzeda filmu. Podobnie jak konferencja, strona filmu czy Facebook. Musi być kampania reklamowa, trzeba kupić media, wywiesić outdoory. Nasz budżet składa się z tzw. „promotion”, czyli materiałów informacyjnych, premiery i innych wydarzeń i reklamy - mówił Salamon. Jak zauważył 
Krzysztof Gierat, dyrektor Krakowskiego Festiwalu Filmowego, wieloletni dystrybutor a obecnie szef agencji promującej krótkie metraże i dokumenty - Krakowskiej Fundacji Filmowej, rynek dystrybucji podlegał w ostatnich 25 latach ogromnym zmianom. - Lista Schindlera na 12 kopiach osiągnęła sukces (900 tysięcy widzów). Dzisiaj wprowadzenie filmu poniżej 100 ekranów jest porażką - powiedział Gierat, mówiąc o trudnościach, jakie musi pokonać dystrybutor w obecnej rzeczywistości.

Bardzo ciekawym wątkiem konferencji były relacje między producentem a dystrybutorem, o których trafnie mówił Dariusz Jabłoński, szef firmy producenckiej Apple Film Production, producent m.in. Poklosia i ostatnich filmów Urszuli Antoniak. Jak zauważył, rola dystrybutora zmienia się wraz z rodzajem filmu. Produkcję można podzielić na film artystyczny, film środka i film komercyjny. - Wraz ze skalą wzrasta rola dystrybutora. Mam wrażenie, że rola dystrybutora w filmie artystycznym jest czasem zbyt duża. Musimy dać wolność reżyserowi, bo jeśli tego nie zrobimy, dostaniemy film nijaki - mówił Jabłoński. - Przy filmie środka rola dystrybutora wzrasta. Film komercyjny „poluje na publiczność w sposób nieograniczony”. Wtedy słucham dystrybutora, bo on wie, jak ludzi przyciągnąć, sprawić, by był dla nich atrakcyjny - mówił Jabłoński.

Organizatorzy konferencji zadbali także o obecność filmu dokumentalnego w dyskursie. Mówił o nim doc. Krzysztof Kopczyński, doświadczony reżyser i producent filmowy, szef firmy Eureka Media. W niezwykle ciekawym, pełnym faktów i danych wystąpieniu zwracał uwagę na osobną sytuację europejskiego dokumentu, który przede wszystkim czerpie przychody $\mathrm{z}$ dystrybucji telewizyjnej. W Europie z rynku telewizyjnego pochodzi 80 proc. wpływów, 20 proc. z VOD, obiegu festiwalowego, sprzedaży nośników.

O europejskich mechanizmach wsparcia dystrybucji filmów mówiła Joanna Wendorff-Østergaard, była dyrektor polskiego biura programu MEDIA, zaś o zmieniającej się roli krytyki w upowszechnianiu kultury filmowej - redaktor Janusz Wróblewski z „Polityki”. Dziennikarz zwrócił 
uwagę, że dzisiaj Złota Palma w Cannes czy inna prestiżowa nagroda nie jest już gwarancją sukcesu frekwencyjnego, bo nawet najgłośniejsze i najczęściej omawiane w mediach filmy ściągają do kin zaledwie kilkanaście tysięcy widzów. - Na większość blockbusterów nie ma wpływu opinia krytyka, bo filmy te mają swoich fanów. Tylko w przypadku kina artystycznego można mówić o rozwoju krytyki, choć czasem ten wpływ jest enigmatyczny - mówił Wróblewski.

To tylko część wystąpień, które złożyły się na program tej bardzo interesującej konferencji, umiejętnie moderowanej przez filmoznawcę dr. Konrada Klejsę z Uniwersytetu Łódzkiego i badacza kultury produkcji dr. Marcina Adamczaka z Uniwersytetu Adama Mickiewicza w Poznaniu.

Dialog badaczy z profesjonalistami, choć często polemiczny, ukazał potrzebę zwiększenia zainteresowania nauki studiami nad filmem, pojmowanym jako przemysł kultury, podatnym na zmiany rynkowe, na napięcia rynku polskiego, europejskiego i globalnego. Efektem konferencji ma być wydawnictwo Szkoły Filmowej w Łodzi, w całości poświęcone zawiłej tematyce dystrybucji filmowej we współczesnych realiach. 


\section{Wydawnictwo Uniwersytetu Kardynała Stefana Wyszyńskiego}

Polecamy ostatnio wydane publikacje
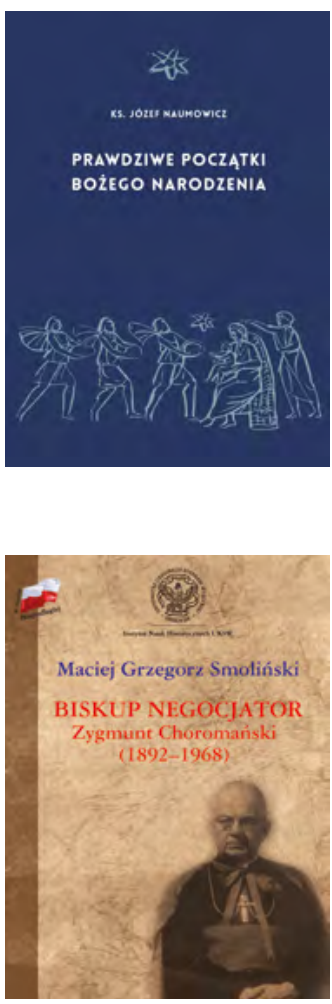

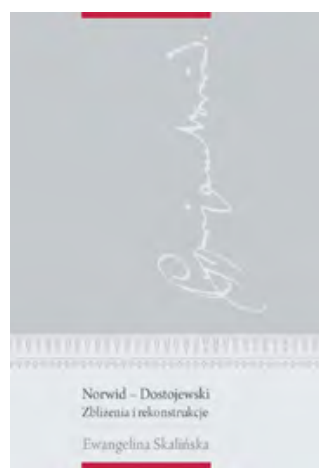

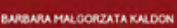

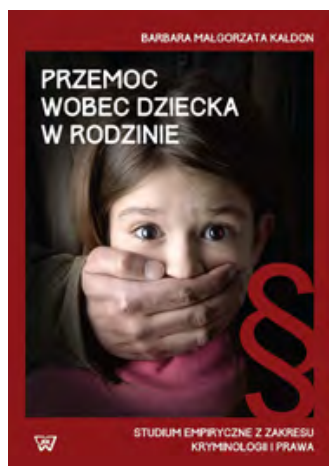

$W^{\text {ydawnictwo UKSW pu- }}$ blikuje książki naukowe i popularnonaukowe: monografie, rozprawy doktorskie i habilitacyjne, tomiki poezji, materiały pokonferencyjne, podręczniki i prace zbiorowe, o tematyce obejmującej wszystkie dziedziny, w których Uniwersytet Kardynał Stefana Wyszyńskiego prowadzi badania naukowe oraz kształcenie.

Wydawnictwo UKSW ul. Dewajtis 5, Warszawa tel. 225618838 